\title{
GMR
}

\section{Inducing autotetraploids in cassava using oryzalin and colchicine and their in vitro morphophysiological effects}

\author{
M. de J. da S. de Carvalho', V.B. Gomes ${ }^{1}$, A. da S. Souza ${ }^{2}$, F.F. Aud ${ }^{2}$, \\ J.A. Santos-Serejo ${ }^{2}$ and E.J. Oliveira ${ }^{2}$ \\ ${ }^{1}$ Centro de Ciências Agrárias Ambientais e Biológicas, \\ Universidade Federal do Recôncavo da Bahia, Cruz das Almas, BA, Brasil \\ ${ }^{2}$ Núcleo de Recursos Genéticos e Desenvolvimento de Variedades, \\ Embrapa Mandioca e Fruticultura, Cruz das Almas, BA, Brasil \\ Corresponding author: E.J. Oliveira \\ E-mail: eder.oliveira@embrapa.br
}

Genet. Mol. Res. 15 (2): gmr.15028281

Received December 15, 2015

Accepted February 11, 2016

Published June 21, 2016

DOI http://dx.doi.org/10.4238/gmr.15028281

\begin{abstract}
Polyploid induction has been used for plant breeding to produce bigger and more robust plants than diploid types. The present study aimed to develop a methodology for in vitro induction of polyploidy in cassava. Apical and lateral microcuttings from the BRS Formosa variety were treated with six oryzalin concentrations for 24 and $48 \mathrm{~h}$. The same methodology was used for colchicine with different concentrations. After 45 days of cultivation and an additional 45 days of subculture, the viability of the explants was assessed and plant acclimatization was performed. Ploidy was determined using flow cytometry. Oryzalin dose and exposure negatively affected cassava explant growth and development compared to untreated explants. Furthermore, apical and lateral explants responded differently to the treatments, showing a diversity in antimitotic sensitivity and effect that is tissue-type specific. In contrast, the doses of 1.25 to $6.25 \mathrm{mM}$ colchicine resulted in high mortality of cassava explants. Therefore,
\end{abstract}


the type of antimitotic affects the morphophysiological behavior of cassava plants in vitro, although apical explants have higher viability and regenerative capacity compared to lateral explants. In addition, the lateral explants have lower mixoploid rates compared to apical explants. Of the 310 plants generated by oryzalin treatments, 277 were diploid, 31 were mixoploid, and 2 were tetraploid. Exposure to oryzalin led to low rate of tetraploids and colchicine caused phytotoxic reactions and death of the explants. The tetraploids were multiplied in vitro to evaluate their yield in the field as well as their behavior against abiotic and biotic stress.

Key words: Antimitotic; Manihot esculenta Crantz; Tissue culture; Flow cytometry; Polyploidy

\section{INTRODUCTION}

Important advances in cassava (Manihot esculenta Crantz) yield have been obtained in recent years using classical breeding methods (Nassar and Ortiz, 2010; Lai et al., 2015). However, similar to other crops (Edgerton, 2009), it is necessary to link the biotechnological tools with conventional breeding strategies to ensure constant improvement in cassava yield.

Polyploidization has been identified as an effective methodology in plant breeding as polyploidy is often related to increased drought resistance, high root yield in tuberous species, and increased protein and nutritional content (Hashimoto-Freitas, 2013). Furthermore, polyploidization has been used to propagate the sterile cassava hybrid (Nassar, 2000) and to increase the rate of apomixis (Nassar, 2006), thereby enabling asexual reproduction of the mother plant. Conventional plant breeding has important obstacles to overcome; such as the time it takes to generate new cassava varieties (Oliveira et al., 2012) and the inherent difficulty of propagating certain cassava genotypes that do not produce flowers. Therefore, chromosomal duplication can accelerate some steps of breeding programs, especially those related to hybridization and initial selection of seedlings.

On the other hand, many factors can determine the success of in vitro polyploidization in cassava, such as the variety, kind of explant, and concentration, exposure, and kind of antimitotic treatment. The interaction of these factors can also affect the ploidy of cassava (Kermani et al., 2003; Costa et al., 2011; Pereira et al., 2012). Polyploidization has been part of the development of protocols for cultivation improvement in crop plants aimed to develop more productive varieties or those with some traits that ensure greater competitiveness of the polyploid in comparison with diploid varieties (Cola et al., 2014; Sinski et al., 2014). For example, Lebot (2009) reported a positive correlation between ploidy and yield in yams where diploid, triploid, and tetraploid varieties produced on average 2.0, 2.5, and $3.0 \mathrm{~kg}$ per plant, respectively. Specifically in cassava, some results suggest the possibility of success with polyploidization because the triploid cultivar "Sree Hansha" is considered one of the most productive cassava varieties in India. In addition, the Brazilian cassava variety, "Manebeba Branca", is a natural triploid and is quite tolerant to drought (Nassar, 2006).

Polyploidy can be induced using antimitotics, such as colchicine and oryzalin (Allum et al., 2007; Ascough and Van Staden, 2008; Rêgo et al., 2011). Colchicine is the most widely used and successful antimitotic (Ishigaki et al., 2009; Quesenberry et al., 2010; Souza- 
Kaneshima et al., 2010). However, according to Nassar (2006), colchicine has been used since the 1960s without effective success in the generation of polyploid cassava varieties, probably due to the genetic instability of the plants generated, because they have often presented tissues with different ploidy (mixoploidy). Alternative antimitotics such as oryzalin have been used because of its low toxicity and high in vitro polyploidization activity. Moreover, this antimitotic can be used at lower concentrations but with similar or higher efficiency compared to colchicine (Kermani et al., 2003; Khosravi et al., 2008; Scagliusi et al., 2009; Quesenberry et al., 2010).

Although polyploidization in cassava can contribute to the generation of more competitive varieties, few studies in this area have been conclusive. It is therefore necessary to develop and improve polyploidy induction protocols for cassava. Thus, the present study aims to evaluate the morphophysiological effects of colchicine and oryzalin treatments on in vitro plants and to establish a methodology for in vitro induction of polyploidy in cassava that generates autotetraploid plants.

\section{MATERIAL AND METHODS}

\section{Polyploidy induction with oryzalin}

The effect of oryzalin $\left(\right.$ Supelco $^{\circledR}$ ) concentrations of $0,3,6,9,12$, and $15 \mu \mathrm{M}$ was evaluated using lateral microcutting of the BRS Formosa variety of cassava after 24 and $48 \mathrm{~h}$ of treatment. The explants were placed in liquid medium without oryzalin until the withdrawal of 300 microcuttings. For each treatment, five $250-\mathrm{mL}$ Erlenmeyer flasks each containing 20 $\mathrm{mL}$ culture medium with the antimitotic and five explants, were agitated at $60 \mathrm{rpm}$ in a growth room $\left(27^{\circ} \pm 1^{\circ} \mathrm{C}\right.$; a photoperiod of $16 \mathrm{~h}$ at $30 \mu \mathrm{mol} \cdot \mathrm{m}^{-2} \cdot \mathrm{s}^{-1}$ supplied by compact fluorescent lamps) for either 24 or $48 \mathrm{~h}$.

In addition, the effects of the oryzalin concentrations were evaluated using two explant types from apical and lateral microcuttings after $48 \mathrm{~h}$ of exposure to the antimitotic following the same procedures for establishment and explant cultivation.

\section{Polyploidy induction with colchicine}

Similar to the oryzalin treatment, lateral microcuttings from the cassava variety BRS Formosa were treated with colchicine $\left(\mathrm{Sigma}^{\circledR}\right)$ concentrations of $0.0,1.25,2.5,3.75,5.0$, and $6.25 \mathrm{mM}$ for 24 or $48 \mathrm{~h}$. In this experiment, the effects of different colchicine concentrations in explant types from apical and lateral microcuttings were analyzed after $48 \mathrm{~h}$ of exposure to colchicine. The establishment and explant cultivation were similar to the first experiment for oryzalin treatment.

\section{Growing conditions}

After the antimitotic treatments, the explants were washed three times in autoclaved Milli-Q water. Then, a cut was made at the ends of each microcutting and the explants were transferred to test tubes (one explant per tube) containing $10 \mathrm{~mL}$ semi-solid culture media. These tubes were then transferred to the growth room at $27^{\circ} \pm 1^{\circ} \mathrm{C}$ and a photoperiod of $16 \mathrm{~h}$ at $30 \mu \mathrm{mol} \cdot \mathrm{m}^{-2} \cdot \mathrm{s}^{-1}$.

The MS culture medium (Murashige and Skoog, 1962) was supplemented with 0.01 
$\mathrm{mg} / \mathrm{L}$ naphthaleneacetic acid, benzylaminopurine, and gibberellic acid before the solution was adjusted to $\mathrm{pH}$ 5.8. Liquid medium was used during the treatments and medium solidified with Phytagel $^{\circledR}(2.4 \mathrm{~g} / \mathrm{L})$ was used for the establishment of plants.

The viability of the explants was analyzed 45 days after cultivation using the following traits: 1) plant height in $\mathrm{cm}$; 2) number of green leaves (NGL); 3) number of microcuttings (NM), and 4) number of roots (NR). Subculture was conducted by identifying microcuttings from plants of each repetition depending on the treatment. After another 45 days of cultivation, a second assessment of the viability of the explants was performed observing the same traits previously measured. The plants were then acclimated in a green house.

\section{Plant acclimation}

For acclimation, the plant roots were washed with water to remove the culture medium and then transferred to plastic bags containing a mixture of Vivato ${ }^{\circledR}$ substrate, topsoil, and coconut fiber (1:1:1). After planting and watering, the plants were covered with plastic cups to prevent water loss. The plastic cups were removed when the plants reached the top of the cup.

\section{Ploidy analysis}

The in vitro plants were analyzed using flow cytometry to identify autotetraploids. Approximately $60 \mathrm{mg}$ leaf tissue from the cassava plants generated by ploidy induction, along with samples of tangerine "Sunki Maravilha" (Citrus sunki Hort ex Tan.) that were used as an internal reference standard $(2 \mathrm{C}=0.745 \mathrm{pg})$, were ground on a Petri dish containing $1 \mathrm{~mL}$ LB01 buffer (Doležel J and Bartoš, 2005) with the aid of a steel blade and kept on ice to release the nuclei. The nucleus suspensions were aspirated using a pipette and filtered through a $30-\mu \mathrm{m}$ mesh. Samples were stained with $25 \mu \mathrm{L}$ propidium iodide and stored in the dark at a low temperature during the sample analysis. To measure the fluorescence of nuclei stained with propidium iodide, an Attune ${ }^{\circledR}$ acoustic focusing flow cytometer (Life Technologies) was used and accounted for at least 10 thousand events.

\section{Experimental design and data analysis}

The experiments were completely randomized in a factorial design with each plot containing one microcutting per test tube. The data were subjected to analysis of variance (ANOVA). The averages of the oryzalin concentrations were compared using the Scott-Knott test at $5 \%$ probability. For colchicine treatments, only the percentage of plant survival was calculated due to high explant mortality. The traits NGL, NM, and NR were transformed to $\sqrt{x+0.5}$ in order to meet the assumptions of ANOVA. Statistical analyses were performed using the SAS statistical software - statistical analysis system (SAS Institute, 2004).

\section{RESULTS AND DISCUSSION}

\section{Effect of oryzalin concentration and exposure time on cassava explant growth and development}

In general, the increase in oryzalin concentration and the exposure time to the 
antimitotic treatment affected the in vitro development of cassava plants when the average reduction in plant height $(62.67 \%)$, number of green leaves $(44.62 \%)$, number of roots $(70.75 \%)$, and number of microcuttings $(46.70 \%)$ were measured (Figure 1). Awoleye et al. (1994) reported a similar but smaller survival percentage, number of regenerated plants, number of intermodal segments, and length of shoots with increasing concentrations of colchicine and oryzalin in cassava compared to our results. The authors also reported a reduction in plant growth from 0 to $45 \%$ (control and $10 \mathrm{mM}$ ) and 0 to $100 \%$ (control and $60 \mu \mathrm{M}$ ) in the colchicine and oryzalin treatments, respectively. Reduced survival of banana (Costa et al., 2011) and rose explants (Khosravi et al., 2008) was also observed with the use of oryzalin. In contrast, colchicine promotes a greater recovery rate of stable tetraploids in Eriobotrya japonica (Thunb.) Lindl., despite its high explant mortality (Blasco et al., 2015). According to Blasco et al. (2015), the percentage of explant survival was $100 \%$ in the control and $70.8 \%$ in the treatments with $0.05 \%$ colchicine after three days of exposure. These results emphasize that the survival of explants decreases with increasing concentration and exposure time of the antimitotic (Xie et al., 2015).

The 48-h exposure time to a liquid culture environment limited the growth of the explants regardless of the presence of oryzalin (Figure 1), indicating that the cassava explants have high sensitivity to liquid medium cultivation. According to Karasawa et al. (2002), in tissue culture, the physical state of the culture medium has a fundamental effect on the morphogenesis and growth of the shoots, which can cause serious problems in the development of explants. However, other authors report that liquid medium could successfully be adopted for multiplication of potato seedlings (Pereira and Fortes, 2003, 2004), banana (de Siqueira et al., 2013), and pineapple (Barboza et al., 2009).
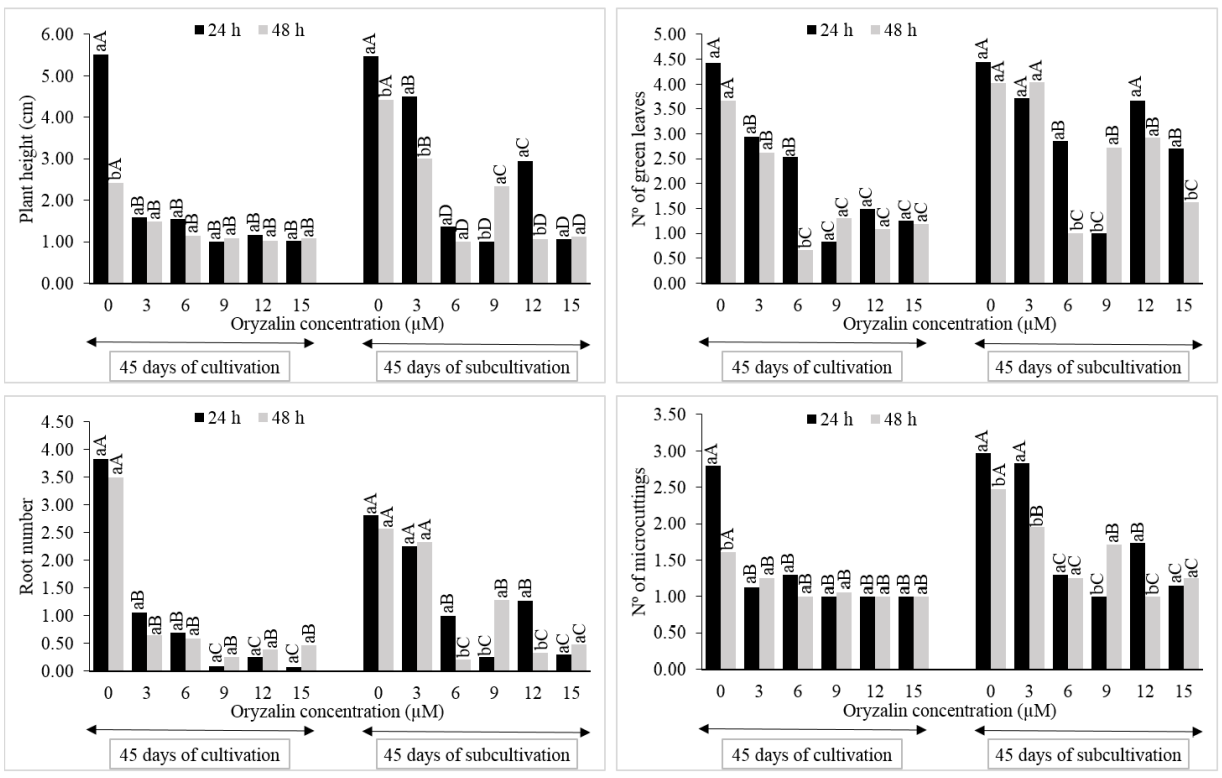

Figure 1. Mean values of plant height $(\mathrm{cm})$, number of green leaves, root number, and number of microcuttings from cassava explants treated with different oryzalin concentrations for 24 or $48 \mathrm{~h}$ in two cultivation periods. Means followed by the same letters are not statistically different by the Scott-Knott test $(\mathrm{P}<0.05)$. Means followed by the same lowercase letters compare the exposure time at each oryzalin concentration and capital letters compare different oryzalin concentrations for each exposure time. 
Regarding the successful generation of autopolyploid plants, Allum et al. (2007) reported that the combination of high antimitotic doses and long exposure times can double the DNA content, resulting in high ploidy levels and the generation of several mixoploids. Therefore, it is important to evaluate cultivation under different exposure times and antimitotic concentrations of cassava apical and lateral explants because these conditions might vary for each species and type of material used (Pereira et al., 2012).

After 45 days of subculture, it was important to assess the best conditions for optimal plant development according to the evaluation traits (Figure 1). Improvement in plant development after treatment is likely due to reduced phytotoxicity of the antimitotic, favoring the regenerative capacity of the explants and their major development. Costa et al. (2011) made similar observations when assessing the high morphogenetic capacity of banana explants after successive subculture in fresh media.

Regardless of the oryzalin concentration, higher NGL and NR averages were observed in the subcultivation (without oryzalin), except for NR in the absence of the antimitotic (Figure 1). The 24-h immersion in oryzalin had less effect on NGL, except at the $9 \mu \mathrm{M}$ concentration. High NGL averages were observed in the control (no oryzalin). The oryzalin concentrations of 3 and $6 \mu \mathrm{M}$ were the most favorable for not significantly compromising plant growth, as these concentrations did not drastically affect the NGL values.

In the subcultivation, a high number of microcuttings was observed in the absence of oryzalin and the exposure time of $24 \mathrm{~h}$, except for the 9 and $15 \mu \mathrm{M}$ oryzalin comparing to the other concentrations (Figure 1). The highest NM was associated with the major development in the absence of an antimitotic, showing significant differences between the explants treated with antimitotic in comparison with the control.

Table 1 shows the number of surviving explants after exposure to the antimitotic.

Table 1. Ploidy levels as a percentage of cassava plants from explants subjected to different oryzalin concentrations and two exposure times.

\begin{tabular}{|c|c|c|c|c|c|}
\hline \multirow[t]{2}{*}{ Oryzalin concentration $(\mu \mathrm{M})$} & \multirow{2}{*}{$\begin{array}{l}\text { Immersion time } \\
\text { (h) }\end{array}$} & \multirow{2}{*}{$\begin{array}{c}\mathrm{N}^{\circ} \text { of surviving } \\
\text { explants }\end{array}$} & \multicolumn{3}{|c|}{ Ploidy of surviving explants (\%) } \\
\hline & & & Diploid & Tetraploid & Mixoploid \\
\hline 0 & 24 & 23 & 100.00 & - & - \\
\hline$\overline{0}$ & 48 & 22 & 100.00 & - & - \\
\hline 3 & 24 & 16 & 87.50 & - & 12.50 \\
\hline 3 & 48 & 14 & 92.86 & - & 7.14 \\
\hline 6 & 24 & 12 & 100.00 & - & - \\
\hline 6 & 48 & 6 & 100.00 & - & - \\
\hline 9 & 24 & 8 & 62.50 & - & 37.50 \\
\hline 9 & 48 & 10 & 70.00 & - & 30.00 \\
\hline 12 & 24 & 4 & 75.00 & - & 25.00 \\
\hline 12 & 48 & 7 & 71.43 & - & 28.57 \\
\hline 15 & 24 & 7 & 100.00 & - & - \\
\hline 15 & 48 & 9 & 55.56 & 11.11 & 33.33 \\
\hline
\end{tabular}

Of the 138 plants analyzed by flow cytometry, most were considered diploid (122), 15 plants were considered mixoploids and only 1 tetraploid. Of the 15 mixoploid plants, nine were from explants subjected to $48 \mathrm{~h}$ of immersion in oryzalin, with the tetraploid plants derived from explants immersed for $48 \mathrm{~h}$ in $15 \mu \mathrm{M}$ oryzalin (Table 1). Therefore, in this experiment with oryzalin, the highest concentration of the antimitotic was most promising for the production of cassava tetraploid plants, although the increase in its concentration can significantly increase plant mortality as well as the probability of a doubling of the DNA content (Allum et al., 2007). 
In grapes (Vitis x Muscadinia hybrids), the treatment of explants with $30 \mu \mathrm{M}$ oryzalin for $24 \mathrm{~h}$ resulted in $22.09 \%$ occurrence of tetraploids, while treatment with $625 \mu \mathrm{M}$ colchicine for $72 \mathrm{~h}$ resulted in $35.08 \%$ occurrence of tetraploids (Xie et al., 2015). In orchid, the use of $0.1 \%$ colchicine for 7 days and $0.003 \%$ oryzalin for 1 or 2 days maximized polyploid production potential (Chung et al., 2014). There is a large difference in the percentage of polyploid generated in this study compared to other published studies, which can be associated with the different behavior of cassava compared to the other species mentioned. In addition, using high concentrations of the antimitotics and different incubation times may have contributed to differences in our results compared to those papers. Indeed, Pereira et al. (2012) suggests that the success of chromosome doubling, especially when considering the efficiency and toxicity of the antimitotic, varies between and within species.

Plants that presented tissues with different ploidies (mixoploids) were not considered for the polyploidization calculation. In the oryzalin treatment, all mixoploid plants showed more diploid cells and were not maintained in vitro. This may be due to over-cultivation of these plants wherein they would become completely diploid over time. Awoleye et al. (1994) has reported that most frequent mixoploid combinations in cassava plants were mixtures of diploid and tetraploid cells in leaf tissues ( $90.4 \%$ of plants analyzed).

The number of nuclei as a function of the inflorescence density in diploid, tetraploid, and mixoploid plants and the amplitude coefficient of variation (CV) between the standard sample and the test samples are shown in Figure 2. The coefficient of variation was between 4.80 and $7.34 \%$, higher than that found by Awoleye et al. (1994) in in vitro experiments for chromosome doubling in cassava (1 to $3 \%$ ).
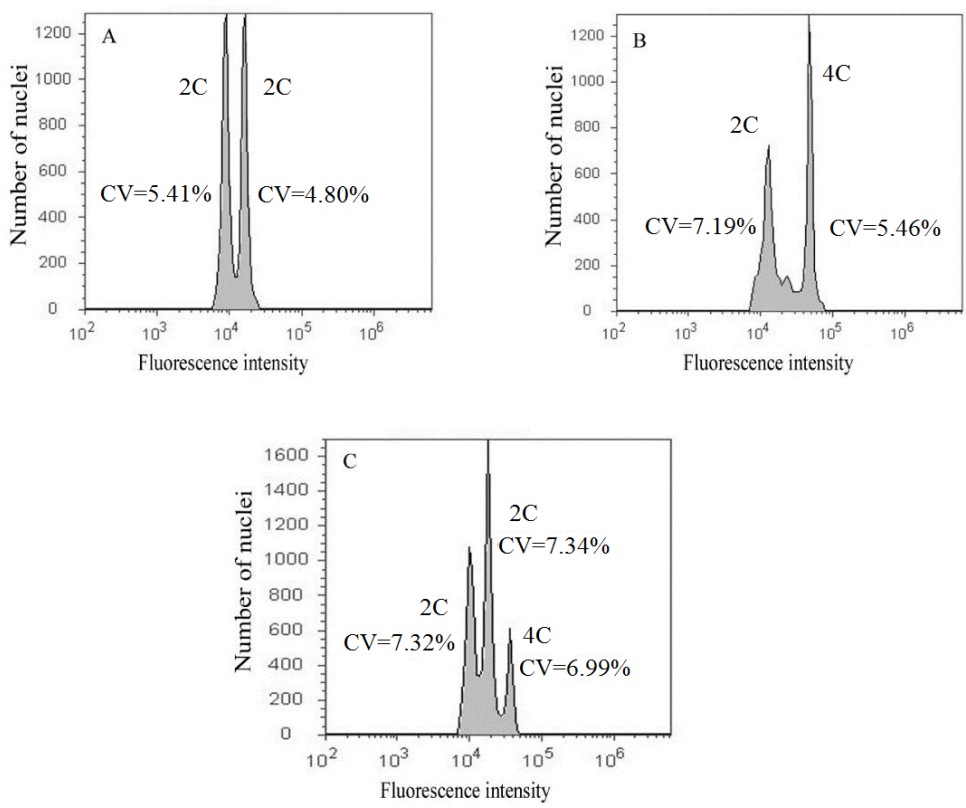

Figure 2. Propidium iodide fluorescence density histogram of cassava in response to oryzalin treatment. Nuclei measurements for (A) diploid, (B) tetraploid, and (C) mixoploid cassava plants. The first peak refers to the reference standard and the other peaks represent the "BRS Formosa" plants. $2 \mathrm{C}$ and $4 \mathrm{C}$ : two and four chromosome sets. CV = coefficient of variation. 


\section{Effect of kind of explant and oryzalin concentration on cassava growth}

The apical explants showed higher viability and regenerative capacity compared with the lateral explants after exposure to different oryzalin concentrations (Figure 3). Similar results were reported in other studies on cassava polyploidization, in which apical explants showed a higher survival rate, number of regenerated plants, average number of intermodal segments, and average length of shoots (Awoleye et al., 1994).

The oryzalin concentration and kind of explant affected the in vitro development of cassava, as shown by the average reduction of plant height (54.51 and 50.57\% for apical and lateral explants, respectively), number of green shoots ( 34.33 and $59.25 \%$ for apical and lateral explants, respectively), number of roots (38.99 and $64.19 \%$ for apical and lateral explants, respectively) and number of microcuttings ( 49.55 and $38.40 \%$ for apical and lateral explants, respectively) (Figure 3). Awoleye et al. (1994) also showed a decrease in plant growth from apical and lateral explants, when treated with colchicine and oryzalin.

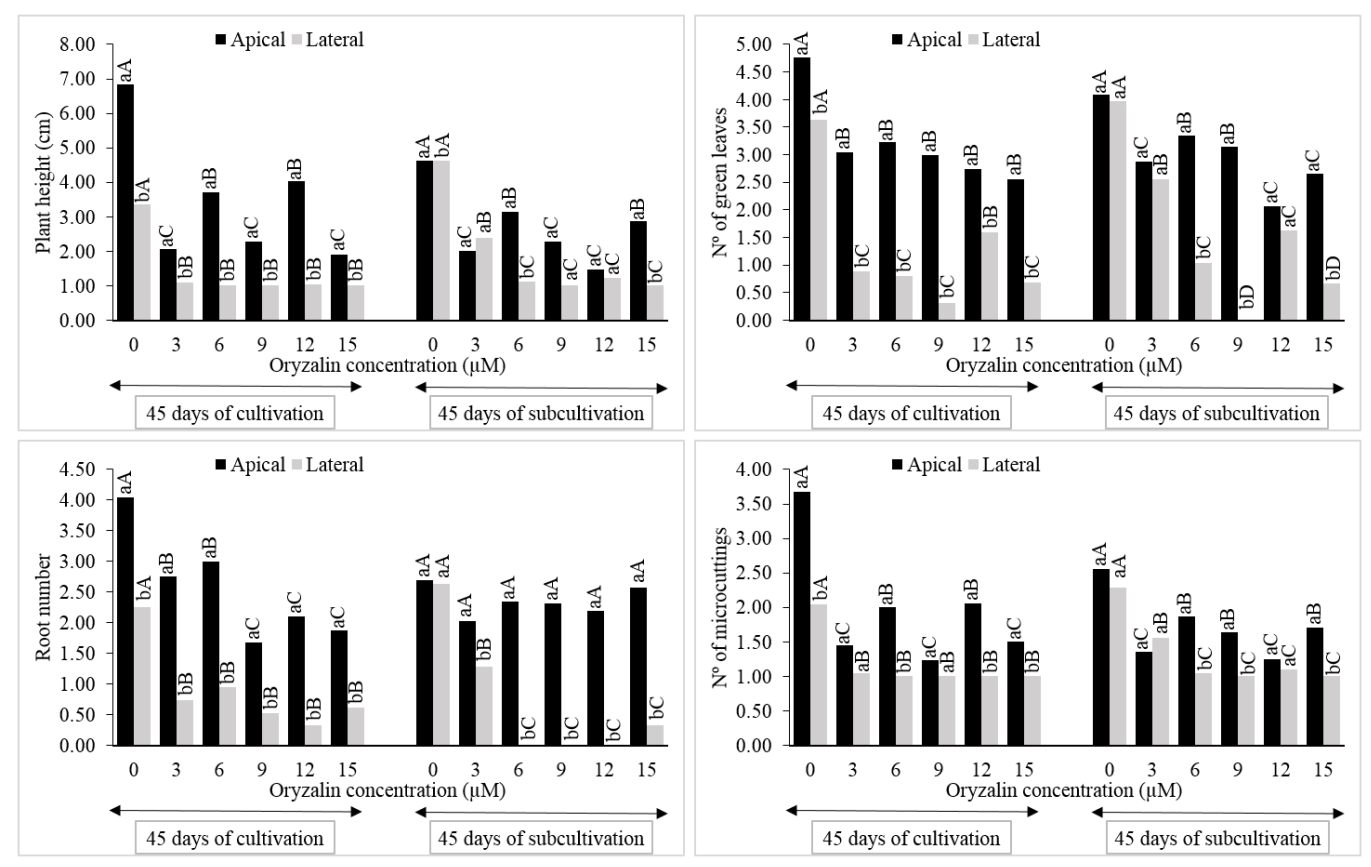

Figure 3. Mean values of plant height $(\mathrm{cm})$, number of green leaves, root number, and number of microcuttings from apical and lateral cassava explants treated with different oryzalin concentrations. Means followed by the same letters are not statistically different by the Scott-Knott test $(\mathrm{P}<0.05)$. Lower case letters compare different types of explants in each oryzalin concentration and capital letters compare different oryzalin concentrations in each type of explant.

Plant viability and regenerative capacity from apical and lateral explants were similar to those obtained from the previous experiment using different oryzalin concentrations, in which there was a decreasing trend in the vegetative development of the explants in higher oryzalin concentrations (Figure 3). However, the lateral explants were more sensitive to treatment with oryzalin. One possible reason for this increased sensitivity may be that lateral 
explants were sectioned at the ends and thereby facilitated the penetration of the antimitotic, resulting in reduced regenerative and development capacity, which is not very evident in apical explants, once these explants are sectioned in the basal ends of the microcuttings.

One of the traits of lateral explants that most severely affected by high oryzalin concentrations is the low number of roots, particularly in concentrations above $3 \mu \mathrm{M}$ (Figure 3 ). This reduction in root development may be associated with the phytotoxic effect of the antimitotic, which may have affected the endogenous hormonal balance of auxin and cytokinin and therefore, the inhibition or reduction of root development as a function of the difference in the metabolism of auxin. Lemos (2010) suggests that the auxin flow is the key conduit for differentiation of vascular tissues and in root formation and development.

Of the 172 explants analyzed using flow cytometry, 155 were considered diploid, 16 mixoploid and 1 tetraploid. Of the 16 mixoploid plants, 12 were from apical explants and the other from lateral explants. The tetraploids originated from apical explants subjected to treatment with $3 \mu \mathrm{M}$ oryzalin (Table 2). In most antimitotic treatments, the apical explants generated a higher percentage of mixoploids and a smaller percentage of diploids compared to lateral explants (Table 2). Similar to the previous experiment, there were a similar number of nuclei as a function of the inflorescence density in diploid plants, tetraploid and mixoploids. Additionally, the amplitude CV between the standard sample and the treated plants was also similar to our previous experiment with oryzalin. Furthermore, most mixoploid plants showed a higher number of diploid cells compared to the tetraploid.

Table 2. Ploidy levels as a percentage of cassava plants from apical and lateral explants subjected to different
oryzalin concentrations.
\begin{tabular}{l|l|c|c|c|c}
\hline \multirow{2}{*}{ Oryzalin concentration $(\mu \mathrm{M})$} & Type of explant & $\mathrm{N}^{\circ}$ of surviving explants & \multicolumn{3}{c}{ Ploidy of surviving explants (\%) } \\
\cline { 4 - 6 } & & & Diploid & Tetraploid & Mixoploid \\
\hline 0 & Apical & 25 & 100.00 & - & - \\
\hline 0 & Lateral & 20 & 100.00 & - & - \\
\hline 3 & Apical & 23 & 78.26 & 4.35 & 17.39 \\
\hline 3 & Lateral & 16 & 75.00 & - & 25.00 \\
\hline 6 & Apical & 22 & 81.82 & - & 18.18 \\
\hline 6 & Lateral & 10 & 100.00 & - & - \\
\hline 9 & Apical & 18 & 94.44 & - & 5.56 \\
\hline 9 & Lateral & 8 & 100.00 & - & - \\
\hline 12 & Apical & 15 & 93.33 & - & 6.67 \\
\hline 12 & Lateral & 5 & 100.00 & - & - \\
\hline 15 & Apical & 10 & 80.00 & - & 20.00 \\
\hline 15 & Lateral & 0 & - & - & - \\
\hline
\end{tabular}

One hypothesis that explains why we observed more mixoploid plants from apical rather than lateral explants may be that such materials already contain active cells with an eminent ability to divide many times when exposed to antimitotics (Lee et al., 2010). Furthermore, meristematic cells have low synchronism in the cell division process (Torres et al., 2003), and so the antimitotic can act at different times in the division phase of different cells. This may give an opportunity for certain cells to go through two processes of duplication while other cells only get one duplication process in the same meristem and thus, result in mixoploidy. This can particularly occur when the explants are exposed to the antimitotic for long periods of time. In contrast, obtaining a tetraploid plant using apical explants with $3 \mu \mathrm{M}$ oryzalin can be explained by the low concentration of this antimitotic inducing a single and uniform cell division. 
For lateral microcuttings of cassava with apical dominance, the cells of the lateral bud only become active in the absence of the apical microcutting after the action of hormones that act on the new apical bud. According to Li et al. (1995), the excision of the apex in pea plants causes an increase of endogenous levels of cytokinins that result in the production of lateral buds inhibited by apical dominance. Furthermore, Li and Bangerth (2003) suggest that lateral buds are negatively regulated by indolacetic acid and cytokinins promote growth by releasing this inhibition; other studies indicate that cytokines biosynthesized on a stem can be transported to the axillary buds after their removal (Dun et al., 2006). However, Dun et al. (2006) suggests that auxin deficiency alone is not enough to trigger the initial growth of the lateral bud. Further, Ferguson and Beveridge (2009) suggest that the factors mentioned above contribute to the reduction of the expression of inhibitory branching genes and that a dormant bud must first enter into a transition state before undergoing growth. Therefore, the cells of the lateral explants that are active after a certain exposure time to antimitotics are less likely to go through more than one cell division and generate a lower amount of mixoploid plants.

Despite having less regenerative capacity, plants from lateral microcuttings presented few mixoploids compared with plants from apical explants, which showed better regenerative capacity. These results are similar to those reported by Awoleye et al. (1994) using these types of explants. Therefore, the results from this study reinforce that the kind of explant used in polyploidy induction can provide different outcomes in response to the antimitotic treatment concentrations (Pereira et al., 2012).

\section{Effect of colchicine on the survival of cassava explants}

The 1.25- to 6.25 -mM colchicine doses resulted in high mortality of cassava explants, suggesting that residual accumulation of this antimitotic causes a phytotoxic effect. In both experiments only the control presented a high survival percentage, regardless of the exposure time to the liquid media (Figure 4). In addition, Awoleye et al. (1994) found that 24\% of explants survived from the cassava cultivar "Colombia 22" when it was subjected to treatment with $10.0 \mathrm{mM}$ colchicine and there was $84 \%$ explant survival in the control. These results suggest that there are different levels of sensitivity to colchicine depending on the cassava variety used in the treatments. Khosravi et al. (2008) reported that the success in chromosomal doubling in rose depends on the genotype evaluated and the ploidy level of the species, where low ploidy levels were more prone to chromosomal doubling. According to these authors the application of $6 \mu \mathrm{M}$ oryzalin for $24 \mathrm{~h}$ in Rose persica $(2 \mathrm{n}=2 \mathrm{x}), R$. hybrida $\mathrm{cv}$ Iceberg $(2 \mathrm{n}=$ $3 \mathrm{x})$ and $R$. hybrida cv Akito $(2 \mathrm{n}=4 \mathrm{x})$ resulted in $60.0,6.3$, and $0 \%$ of chromosomal doubling, respectively. Similarly, Pereira et al. (2012) reported that the concentration and exposure time to an antimitotic varies for each species and kind of explant, and that the effect of the interaction between various factors hinders the establishment of an efficient and universal method for chromosome doubling. Therefore, Pereira et al. (2012) suggest that for each species, it is necessary to define a methodology that offers the best results.

Overall, the results of this study differed from those observed by Awoleye et al. (1994) in that oryzalin was less efficient than colchicine in chromosome doubling, being considered an antimitotic of great phytotoxicity in cassava. The main explanation for this discrepancy is the use of different varieties in the present study ("BRS Formosa") and the previous study ("Colombia 22"). The variation between and within a species has been shown to be one of the most important factors that affect the chromosome doubling methodologies (Khosravi et 
al., 2008; Pereira et al., 2012), which may also be related to differences in the morphogenetic potential of genotypes (Nogueira et al., 2001).

Colchicine has been reported as a highly toxic antimitotic in other plant species. In orange explants of "Pera-de-abril" and tangor "Murcott", colchicine is toxic and results in both significant reductions in the average number of adventitious shoots and an increase in the percentage of non-responsive explants (Latado et al., 2007). In banana, an increase in mortality and phytotoxic effects in explants was reported to be dependent on the concentration and exposure time to colchicine (Costa et al., 2011). In contrast, in vine Xie et al. (2015) found no difference in the phytotoxicity between colchicine and oryzalin; although similar to what was observed in the present study, oryzalin has been reported as an excellent antimitotic in several species of plants, such as Watsonia lepidae (Ascough and van Staden, 2008) and Paspalum (Quesenberry et al., 2010).

The four regenerated plants treated with colchicine were also analyzed using flow cytometry and were classified as diploid, showing similar behavior in the number of nuclear density function inflorescence to diploid plants (data not shown).

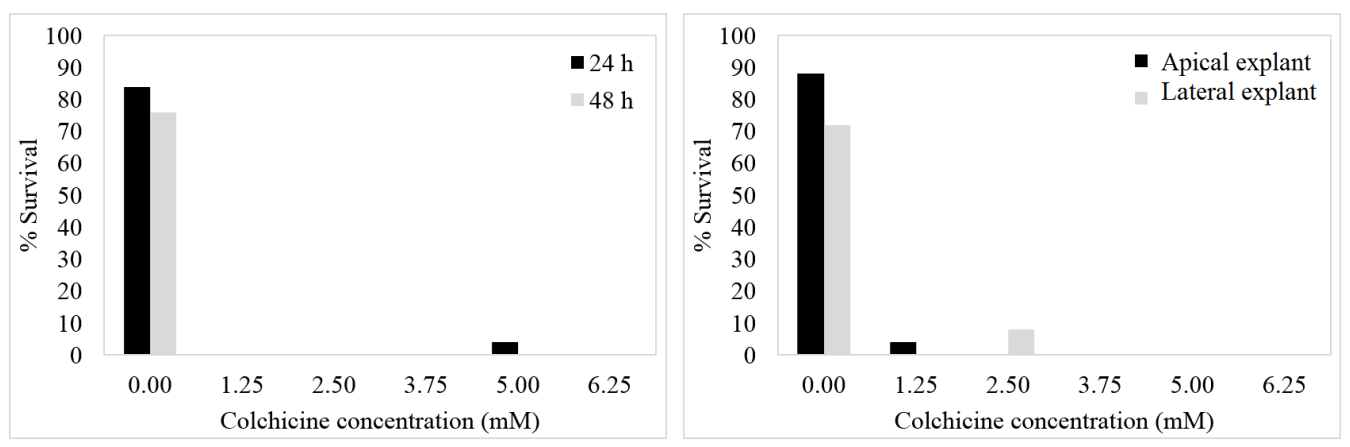

Figure 4. Percentage survival of cassava plants from lateral and apical explants subjected to different colchicine concentrations for 24 and $48 \mathrm{~h}$.

\section{Use of chromosome doubling in cassava}

In addition to the low efficiency in generating tetraploids, the regenerative capacity of cassava explants was negatively affected by the concentration and duration of exposure to antimitotics. The efficiency of in vitro polyploidization in cassava could be increased with the use of smaller explants, the reduction of the antimitotic concentrations, as well as the analysis of different exposure times. Further research in this direction could contribute to a more efficient protocol for chromosomal doubling in cassava. It is also important to consider that the use of low doses of antimitotic has proven inefficient, while excessively high doses have been shown to be lethal. Although the protocol used in the present study has not produced a high rate of tetraploids, our experiments define significant modifications that provide a base for inducing in vitro polyploidy in cassava without inhibiting the viability of regenerating plants.

The mixoploid plants generated in this study were not propagated due to their instability; diploid tissues have a higher growth rate compared to the tetraploid (Nassar, 2006; Costa et al., 2011) and therefore the new growth materials soon become only diploid (Nassar, 2006). Therefore, only the tetraploid plants were multiplied in vitro to further evaluate the 
yield, potential drought tolerance, and resistance to the main pests and diseases that affect the crop, as well as to evaluate the potential of these plants to produce roots with high commercial quality.

In conclusion, oryzalin concentrations $(3$ and $15 \mu \mathrm{M})$ and exposure time affect the in vitro development of cassava plants but produce only a few tetraploid individuals. The apical explants show higher viability and regenerative capacity in relation to lateral explants. Lateral explants generate fewer mixoploids compared with the apical explants and the colchicine concentrations of 1.25 to $6.25 \mathrm{mM}$ cause a phytotoxic effect and hence, death of the explants.

\section{Conflicts of interest}

The authors declare no conflict of interest.

\section{ACKNOWLEDGMENTS}

We would like to thank Embrapa Cassava and Fruit for providing the physical infrastructure and financial support that were essential for conducting these studies. We would also like to thank the Brazilian Federal Agency for Support and Evaluation of Graduate Education (Coordenação de Aperfeiçoamento de Pessoal de Nível Superior - CAPES) for the financial aid scholarships awarded.

\section{REFERENCES}

Allum JF, Bringloe DH and Roberts AV (2007). Chromosome doubling in a Rosa rugosa Thunb. hybrid by exposure of in vitro nodes to oryzalin: the effects of node length, oryzalin concentration and exposure time. Plant Cell Rep. 26: 1977-1984. http://dx.doi.org/10.1007/s00299-007-0411-y

Ascough GD and Van Staden JE (2008). Effectiveness of colchicine and oryzalin at inducing polyploidy in Watsonis lepida N. E. Brown. HortScience 43: 2248-2251.

Awoleye F, Van Duren M, Dolezel J and Novak FJ (1994). Nuclear DNA content and in vitro induced somatic polyploidization cassava (Manihot esculenta Crantz) breeding. Euphytica 76: 195-202. http://dx.doi.org/10.1007/ BF00022164

Barboza SBSC, Teixeira JB, Portes TA, Copati LA, et al. (2009). Cultivo inicial in vitro de gemas axilares de Ananas comosus (L.) Merr., em meio líquido/sólido, na presença/ausência de luz. Cienc. Agrotec. 33: 1832-1836. http:// dx.doi.org/10.1590/S1413-70542009000700022

Blasco M, Badenes LM and Naval M del M (2015). Colchicine-induced polyploidy in loquat (Eriobotrya japonica (Thunb.) Lindl.). Plant Cell Tissue Organ Cult. 120: 453-461. http://dx.doi.org/10.1007/s11240-014-0612-3

Chung MY, Kim CY, Min JS, Lee DJ, et al. (2014). In vitro induction of tetraploids in an interspecific hybrid of Calanthe (Calanthe discolor $\mathrm{x}$ Calanthe sieboldii) through colchicine and oryzalin treatments. Plant Biotechnol. Rep. 8: 251257. http://dx.doi.org/10.1007/s11816-014-0317-4

Cola GPA, Marques AM, Damasceno S, Carvalho CR, et al. (2014). In vitro polyploidization in Solanum lycopersicum Mill. 'Santa Cruz Kada Gigante'. Cytologia (Tokyo) 79: 1-8. http://dx.doi.org/10.1508/cytologia.79.351

Costa FH da S, Pasqual M, Silva S de O e, Silva Neto HP da, et al. (2011). Poliploidização em ápices caulinares de bananeira e seus efeitos morfofisiológicos in vitro. Pesq. Agropec. Bras. 46: 805-813.

de Siqueira DL, dos Santos D, Salomão LCC, Fonseca F, et al. (2013). Micropropagação da bananeira 'Maçã', cultivada in vitro em diferentes volumes de meio líquido. Rev. Ceres 60: 745-751. http://dx.doi.org/10.1590/S0034737X2013000600001

Doležel J and Bartoš J (2005). Plant DNA flow cytometry and estimation of nuclear genome size. Ann. Bot. (Lond.) 95: 99-110. http://dx.doi.org/10.1093/aob/mci005

Dun EA, Ferguson BJ and Beveridge CA (2006). Apical dominance and shoot branching. Divergent opinions or divergent mechanisms? Plant Physiol. 142: 812-819. http://dx.doi.org/10.1104/pp.106.086868

Edgerton MD (2009). Increasing crop productivity to meet global needs for feed, food, and fuel. Plant Physiol. 149: 7-13. http://dx.doi.org/10.1104/pp.108.130195 
Ferguson BJ and Beveridge CA (2009). Roles for auxin, cytokinin, and strigolactone in regulating shoot branching. Plant Physiol. 149: 1929-1944.http://dx.doi.org/10.1104/pp.109.135475

Hashimoto-Freitas DY (2013). Citoquimeras e poliploides totais em Manihot esculenta (mandioca): citogenética, anatomia e ontogenia do saco embrionário. Doctoral thesis, Universidade de Brasília, UnB, Brasília.

Ishigaki G, Gondo T, Suenaga K and Akashi R (2009). Induction of tetraploid ruzigrass (Brachiaria ruziziensis) plants by colchicine treatment of in vitro multiple-shoot clumps and seedlings. Grassland Sci. 55: 164-170. http://dx.doi. org/10.1111/j.1744-697X.2009.00153.x

Karasawa MMG, Pinto JEBP, Pinto JC and Pereira AV (2002). Proliferação de capim elefante em diferentes concentrações de regulador de crescimento e consistências do meio de cultura. Cienc. Agrotec. 26: 1243-1251.

Kermani MJ, Sarasan V, Roberts AV, Yokoya K, et al. (2003). Oryzalin-induced chromosome doubling in Rosa and its effect on plant morphology and pollen viability. Theor. Appl. Genet. 107: 1195-1200. http://dx.doi.org/10.1007/ s00122-003-1374-1

Khosravi P, Kermani MJ, Nematzadeh GA, Bihamta MR, et al. (2008). Role of mitotic inhibitors and genotype on chromosome doubling of Rosa. Euphytica 160: 267-275. http://dx.doi.org/10.1007/s10681-007-9571-7

Lai HG, Chen X, Chen Z, Ye JQ, et al. (2015). Induction of female $2 n$ gametes and creation of tetraploids through sexual hybridization in cassava (Manihot esculenta). Euphytica 201: 265-273. http://dx.doi.org/10.1007/s10681-014-1207-0

Latado RR, Cristofani-Yaly M, Carvalho CR de and Machado MA (2007). Plantas autotetraplóides de citros sob tratamento in vitro com colchicina. Pesquisa Agropecu. Bras. 42: 1429-1435. http://dx.doi.org/10.1590/S0100$\underline{204 X 2007001000009}$

Lebot V (2009). Tropical root and tuber crops: Cassava, Sweet potato, Yams and Aroids. In: Yams (Lebot V, eds.). 17. CABI, Wallingford, 183-275.

Lee EK, Jin YW, Park JH, Yoo YM, et al. (2010). Cultured cambial meristematic cells as a source of plant natural products. Nat. Biotechnol. 28: 1213-1217.http://dx.doi.org/10.1038/nbt.1693

Lemos EEP (2010). Cultivo in vitro de plantas. In: Organogênese (Barrueto Cid LP, eds.). 1. Embrapa Informação Tecnológica: Embrapa Recursos Genéticos e Biotecnologia, Brasília, 103-127.

Li C and Bangerth F (2003). Stimulatory effect of cytokinins and interaction with IAA on the release of lateral buds of pea plants from apical dominance. J. Plant Physiol. 160: 1059-1063. http://dx.doi.org/10.1078/0176-1617-01042

Li CJ, Guevara E, Herrera J and Bangerth F (1995). Effect of apex excision and replacement by 1-naphthylacetic acid on cytokinin concentration and apical dominance in pea plants. Physiol. Plant. 94: 465-469. http://dx.doi. org/10.1111/j.1399-3054.1995.tb00955.x

Murashige T and Skoog F (1962). A revised medium for rapid growth and bioassays with tobacco tissue culture. Physiol. Plant. 15: 473-497. http://dx.doi.org/10.1111/j.1399-3054.1962.tb08052.x

Nassar NMA (2000). Cytogenetics and evolution of Cassava (Manihot esculenta Crantz). Genet. Mol. Biol. 23: 1003-1014. http://dx.doi.org/10.1590/S1415-47572000000400046

Nassar NMA (2006). Mandioca: opção contra a fome: estudos e lições no Brasil e no mundo. Cienc. Hoje 39: 30-39.

Nassar N and Ortiz R (2010). Breeding cassava to feed the poor. Sci. Am. 302: 78-82, 84. http://dx.doi.org/10.1038/ scientificamerican $0510-78$

Nogueira FTS, Costa MG, Figueira ML, Otoni WC, et al. (2001). Regeneração in vitro de plantas de tomateiros 'Santa Clara' e seu mutante natural 'Firme'. Cienc. Agrotec. 25: 63-71.

Oliveira EJ, de Resende MDV, Santos V da S, Ferreira CF, et al. (2012). Genome-wide selection in cassava. Euphytica 187: 263-276. http://dx.doi.org/10.1007/s10681-012-0722-0

Pereira JES and Fortes GRL (2003). Protocolo para produção de material propagativo de batata em meio líquido. Pesquisa Agropecu. Bras. 38: 1035-1043. http://dx.doi.org/10.1590/S0100-204X2003000900003

Pereira JES and Fortes GRL (2004). Organogênese de ápices meristemáticos de batata em meios de isolamento e multiplicação in vitro. Hortic. Bras. 22: 197-201. http://dx.doi.org/10.1590/S0102-05362004000200007

Pereira RC, Davide LC, Techio VH and Timbó ALO (2012). Duplicação cromossômica de gramíneas forrageiras: uma alternativa para programas de melhoramento genético. Cienc. Rural 42: 1278-1285. http://dx.doi.org/10.1590/ $\underline{\text { S0103-84782012000700023 }}$

Quesenberry KH, Dampier JM, Lee YY, Smith RL, et al. (2010). Doubling the chromosome number of bahiagrass via tissue culture. Euphytica 175: 43-50. http://dx.doi.org/10.1007/s10681-010-0165-4

Rêgo MM, Rêgo ER, Bruckner CH, Finger FL, et al. (2011). In vitro induction of autotetraploids from diploid yellow passion fruit mediated by colchicine and oryzalin. Plant Cell Tissue Organ Cult. 107: 451-459. http://dx.doi. org/10.1007/s11240-011-9995-6

Scagliusi SM, Grosselli D, Ruppenthal TE and Deon AZ (2009). Estudos preliminares sobre o efeito da cafeína na duplicação cromossômica em plantas haplóides de cevada (Hordeum vulgare L.). Passo Fundo, Embrapa Trigo. Embrapa Trigo. Documentos Online, 109. Available at [http://www.cnpt.embrapa.br/biblio/do/p_do109.htm]. Accessed May 31, 2015. 
Sinski I, Bosco DD, Pierozzi NI, Maia JDG, et al. (2014). Improving in vitro induction of autopolyploidy in grapevine seedless cultivars. Euphytica 196: 299-311. http://dx.doi.org/10.1007/s10681-013-1034-8

Souza-Kaneshima D, Simioni C, Felismino MF, Mendes-Bonato AB, et al. (2010). Meiotic behavior in the first interspecific hybrids between Brachiaria brizantha and Brachiaria decumbens. Plant Breed. 129: 186-191. http:// dx.doi.org/10.1111/j.1439-0523.2009.01674.x

Torres GA, Davide LC and Bearzoti E (2003). Sincronização do ciclo celular em meristema radicular de baru (Dipteryx alata Vog). Cienc. Agrotec. 27: 398-405.

Xie X, Agüero CB, Wang Y and Walker MA (2015). In vitro induction of tetraploids in Vitis x Muscadinia hybrids. Plant Cell Tissue Organ Cult. 122: 675-683. http://dx.doi.org/10.1007/s11240-015-0801-8 